\title{
COMPARATIVE STUDY OF FIVE DIFFERENT SURGICAL TECHNIQUES FOR THE TREATMENT OF MORBID OBESITY USING BAROS
}

\author{
Comparação de cinco técnicas para o tratamento cirúrgico da obesidade mórbida com o BAROS
}

João Batista MARCHESINI, Jean Ricardo NICARETA

From Clínica Marchesini (Marchesini Clinic) and Hospital de Clínicas da Universidade Federal do Paraná (Clinic Hospital, Federal University of Paraná State), Curitiba, Paraná, Brazil.

HEADINGS - Morbid obesity. Bariatric surgery. Methods.

\section{Correspondence:}

João Batista Marchesini

E-mail: jbmarchesini@hotmail.com

Financial source: none

Conflicts of interest: none

Received for publication: 16/04/2014

Accepted for publication: 24/047/2014

DESCRITORES - Obesidade mórbida. Cirurgia bariátrica. Métodos.
ABSTRACT - Background: The obesity is an universal disease of epidemic proportions and in a growing prevalence. It is one of the main public health problems and it will be inexorably the largest problem of the developing world. The morbid obesity is associated to serious diseases, reducing the life perspective, increasing the morbility and mortality. Several strategies of losing weight were proposed; however, the bariatric surgeries are today the most effective treatment for this disease. The BAROS is the most simple, practical and efficient method to evaluate the results in the bariatric surgeries. Aim: To compare five surgical techniques for the treatment of morbid obesity using BAROS. Method: The sample is constituted of 102 patients submitted to Fobi-Capella (23 patients), Scopinaro (21 patients), duodenal switch (20 patients), vertical banded gastroplasty of Mason (15 patients) and the adjustable gastric band (23 patients), evaluated 12 months after the surgeries using BAROS. Results: The analysis of the final result of BAROS for the classification demonstrated that good, very good and excellent results were obtained in $100 \%$ of the patients in the group of duodenal switch; 91,3\% in Fobi-Capella; 85,7\% in Scopinaro; 60\% in Mason; and $56,5 \%$ in adjustable gastric band. The final result of BAROS for the total score demonstrated that the group of duodenal switch obtained 6,3 points; the Fobi-Capella 5,1 points; the Scopinaro 4,8 points; the Mason 3,0 points; and the adjustable gastric band 2,9 points $(p<0,0001)$. Conclusion: The duodenal switch is the best technique for the surgical treatment of the morbid obesity, in the following 12 months post-surgical clinical procedures, according to BAROS.
RESUMO - Racional: A obesidade é doença universal de proporções epidêmicas e com prevalência crescente. É um dos principais problemas de saúde pública da sociedade moderna e inexoravelmente será o maior problema do mundo desenvolvido. Numerosas estratégias para emagrecer foram propostas nas últimas décadas; porém, as operações bariátricas constituem, hoje, no tratamento mais eficaz desta doença. Inúmeros métodos são usados para avaliar as operações bariátricas, mas o BAROS (Bariatric Analysis and Reporting Outcome System) é o mais simples, prático e eficiente para avaliar os resultados das operações bariátricas. Objetivo: Comparar cinco técnicas operatórias para o tratamento da obesidade mórbida utilizando o BAROS e identificar qual delas é mais efetiva. Métodos: A amostra consistiu de 102 pacientes submetidos a um dos procedimentos: derivação gastrojejunal de Fobi-Capella (23 pacientes), derivação biliopancreática de Scopinaro (21 pacientes), derivação biliopancreática com duodenal switch (20 pacientes), gastroplastia vertical com banda de Mason (15 pacientes) e banda gástrica ajustável (23 pacientes). Foram avaliados 12 meses após as operações utilizando o BAROS. Resultados: Resultado bom, muito bom e excelente foi obtido em $100 \%$ dos pacientes no grupo duodenal switch; $91,3 \%$ no Fobi-Capella; $85,7 \%$ no Scopinaro; $60 \%$ no Mason; e 56,5\% no banda. A análise do resultado final do BAROS pela pontuação total demonstra que o grupo duodenal switch obteve 6,3 pontos; o Fobi-Capella 5,1 pontos; o Scopinaro 4,8 pontos; o Mason 3,0 pontos e o banda 2,9 pontos $(p<0,0001)$. Conclusão: A derivação biliopancreática com duodenal switch é a melhor técnica para o tratamento cirúrgico da obesidade mórbida, no seguimento clínico pós-operatório de 12 meses, segundo o BAROS.

INTRODUCTION

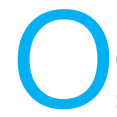

ria and Moorehead introduced BAROS (Bariatric Analysis and Reporting Outcome System) to assess and standardize reports on bariatric surgeries $^{21}$. It comprises assessment of five areas: weight loss, life quality, co-morbidity, complications and redoing surgery. BAROS may also be used to compare results of different surgery techniques carried out by different surgeons.

Through using BAROS ${ }^{21}$, the present work aims at comparing five surgery techniques to treat morbid obesity aiming at identifying which among them is the most effective after a 12-month post-surgical clinical procedure follow-up.

METHODS

The present descriptive and historical study assessed 102 patients at Clínica Marchesini (Marchesini Clinic) in Curitiba, State of Paraná in Brazil, who have undergone bariatric surgeries using five different techniques and with an over 12-month postsurgical clinical procedure follow-up. The patients were assembled in five groups, as follows: Fobi-Capella gastric bypass (23 patients); Scopinaro biliopancreatic diversion (21 patients); duodenal switch biliopancreatic diversion (20 patients); adjustable gastric band (23 patients); and Mason vertical banded grastroplasty (15 patients). All the 
patients were assessed by using BAROS ${ }^{21}$

To carry out statistic analysis the study used Variance Analysis (Anova), Kruskal-Wallis Non-Parametric Test, Fisher Exact Test and Qui-square test. It was also used a significance level inferior to $5 \%(p<0.05)$.

\section{RESULTS}

The study sample comprised 102 patients being 63.7\% of women and age group average 41.2. The post-surgery average body mass index (BMI) was $43.2 \mathrm{~kg} / \mathrm{m}^{2}$; average Mason vertical banded gastroplasty technique $45.8 \mathrm{~kg} / \mathrm{m}^{2}$; FobiCapella gastric bypass $45.3 \mathrm{~kg} / \mathrm{m}^{2}$; Scopinaro biliopancreatic diversion $45 \mathrm{~kg} / \mathrm{m}^{2}$; duodenal switch biliopancreatic diversion $43.4 \mathrm{~kg} / \mathrm{m}^{2}$; and adjustable gastric band $37.6 \mathrm{~kg} / \mathrm{m}^{2}$.

Post-surgery outcomes showed overweight percentage decrease, as follows: duodenal switch biliopancreatic diversion (83.3\%), Fobi-Capella gastric bypass (66.7\%), Scopinaro biliopancreatic diversion (58.7\%), Mason vertical banded gastroplasty (49.6\%) and adjustable gastric band (36.6\%).

Table 1 shows overweight variation between pre and post-surgery comparing the five study techniques. The greatest loss was observed in the duodenal switch biliopancreatic diversion group.

Pre-surgery main co-morbidity were the following: systemic arterial hypertension (75.0\%), arthralgia (47.1\%), esophagitis (44.3\%), dyslipidemia (35.3\%), electrocardiogram alterations (32.8\%), hiatus hernia (29.5\%), lower limb varicose veins $(29.5 \%)$, sleep apnea $(25.0 \%)$, diabetes mellitus type 2 (19.1\%), arthrosis (14.7\%), dyspnea (11.5\%) and gastroesophageal reflux (11.5\%).

Post-surgery clinical condition score assessment shows that $56.9 \%$ of the patients achieved a solution to one $(+2$ points) or all (+ 3 points) co-morbidities. The duodenal switch biliopancreatic diversion group achieved the best result and the adjustable gastric band had the worst result (Table 2).

Table 3 shows life quality results according to the Moorehead-Ardelt questionnaire ${ }^{21}$. The Fobi-Capella gastric bypass group achieved the best result.

Main complications observed were the following: vomit (72), nausea (32), hair loss (30), vitamin, mineral and protein deficiency (25), anemia (21), incisional hernia (15), depression (10), seroma (6), suture dehiscence (4), surgery wound infection (7), peptic ulcer complication (3), anastomosis stenosis (3), gastrogastric fistula (2), respiratory insufficiency (3), and nervous anorexia (2).

The Fobi-Capella gastric bypass group showed the highest rate of significant complications and the adjustable gastric band group showed the highest rate of insignificant complications (Table 4).

It was necessary to redo three surgeries in patients belonging to the Scopinaro biliopancreatic diversion group, three in the duodenal switch biliopancreatic diversion group and one in the adjustable gastric band group.

The study group analysis using BAROS showed the duodenal switch biliopancreatic diversion group achieved the highest final score average and good, very good and excellent highest rates followed by the Fobi-Capella gastric bypass, Scopinaro biliopancreatic diversion, Mason vertical banded gastroplasty and adjustable gastric band groups (Tables 5 e 6).

Group comparison shows that duodenal switch biliopancreatic diversion result is significantly better $(p<0,0001)$ than the other technique results (Table 6B).

\section{DISCUSSION}

In the present study, weight loss is similar to that described in a meta-analysis where it was observed higher weight loss in the duodenal switch biliopancreatic diversion group followed by the Scopinaro biliopancreatic diversion, gastrojejunal diversion, vertical gastroplasty with band and adjustable gastric band groups ${ }^{6}$. But, differently from the metaanalysis, the present study showed that only the duodenal switch biliopancreatic diversion group was able to bring BMI average to the overweight category and the near as possible to the normal weight, that's to say $26.3 \mathrm{~kg} / \mathrm{m}^{2}$.

Through the bibliographic references on the alterations of post-bariatric surgery clinical conditions, it is possible to estimate that Scopinaro biliopancreatic diversion and duodenal switch biliopancreatic diversion are the techniques with the highest disease solution rates. On the other hand, the gastrojejunal diversion shows intermediate results concerning improvement of co-morbidities, and the vertical gastroplasty with band and the adjustable gastric band show the comorbidity solution lowest rates $7,8,9,17,18,19,22,24,25,27,29$, what is similar to the present study findings.

In literature, few papers use Moorehead-Ardelt life quality questionnaire to assess more than one technique and none show life quality within the post-surgery 12 -month follow-up. The only existing paper comparing the three techniques aforementioned showed that patients undergoing gastric band surgery followed by gastric bypass and Mason vertical banded gastroplasty had their life quality improved ${ }^{13}$, differently from what is shown by the present paper findings.

Complication rates identified herein are similar to those described in the relevant literature 3,5,11,14,16,20,24,26.

In the present study, duodenal switch biliopancreatic diversion and Scopinaro biliopancreatic diversion showed the highest surgery redoing rates, differently from what was found in the literature review where vertical banded gastroplasty and adjustable gastric band showed the highest surgery redoing rates and biopancreatic diversions showed the lowest rates 2,3,4,10,11,12,15,16,19,27,28.

Concerning weight loss, when comparing three different BAROS techniques there were no differences between them; however, the best results were observed using Fobi gastrojejunal diversion followed by vertical banded gastroplasty and adjustable gastric band. Co-morbidities improvement was similar in the three techniques. Life quality assessment found that patient well-being showed more improvement after adjustable gastric band than after the other two techniques, but such difference was not statistically significant. However, the laparoscopic procedure seems to give more satisfaction to the patient, even when weight loss is not as significant as it is in other techniques ${ }^{1}$.

A study ${ }^{13}$ which used BAROS to compare vertical banded gastroplasty, Y-de-Roux gastrojejunal diversion and adjustable gastric band showed that $75 \%$ of the patient life quality and health conditions improved significantly when compared to the control group that did not undergo surgery. The three aforementioned techniques showed similar results concerning medical conditions, but weight loss was significantly higher in the gastrojejunal diversion. Regarding weight loss, the Y-de-Roux diversion was superior to the purely restrictive procedures and a little superior concerning life quality and co-morbidities. The study inferred that when using BAROS the Y-de-Roux gastrojejunal diversion was superior to the vertical banded gastroplasty and adjustable gastric band. Thus, the results are consonant to those obtained in the present study.

BAROSassessment of 386 patientswhounderwentMolina gastric band surgery with adjustable silicone ring (Kuzmak), vertical gastroplasty with silastic ring and bilipancreatic diversion shows patients outgoing biliopancreatic diversion achieved the best results among all the techniques ${ }^{30}$.

When BAROS was used to compare 93 patients, it showed that Y-de-Roux gastrojejunal diversion results were superior to vertical banded gastroplasty, mainly because weight loss was superior and easier in gastrojejunal diversion 
TABLE 1 - Overweight loss percent in the study groups classified by score

\begin{tabular}{|c|c|c|c|c|c|c|c|c|c|c|c|c|}
\hline \multirow{2}{*}{ \%WLP ${ }^{(1)}$} & \multicolumn{2}{|c|}{ Fobi-Capella } & \multicolumn{2}{|c|}{ Scopinaro } & \multicolumn{2}{|c|}{ Duodenal switch } & \multicolumn{2}{|c|}{ Band } & \multicolumn{2}{|c|}{ Mason } & \multicolumn{2}{|c|}{ Total } \\
\hline & $\mathrm{n}$ & $\%$ & $\mathrm{n}$ & $\%$ & $\mathrm{n}$ & $\%$ & $\mathrm{n}$ & $\%$ & $\mathrm{n}$ & $\%$ & $\mathrm{n}$ & $\%$ \\
\hline $\begin{array}{l}\text { Weight } \\
\text { gain }\end{array}$ & - & - & - & - & - & - & 01 & 4,4 & - & - & 01 & 1,0 \\
\hline $00-024$ & - & - & - & - & - & - & 06 & 26,1 & 04 & 26,7 & 10 & 9,8 \\
\hline $25-049$ & 04 & 17,4 & 08 & 38,1 & - & - & 09 & 39,1 & 04 & 26,7 & 25 & 24,5 \\
\hline $50-074$ & 11 & 47,8 & 09 & 42,9 & 05 & 25,0 & 05 & 21,7 & 04 & 26,6 & 34 & 33,3 \\
\hline $75-100$ & 08 & 34,8 & 04 & 19,0 & 15 & 75,0 & 02 & 8,7 & 03 & 20,0 & 32 & 31,4 \\
\hline TOTAL & 23 & 100,0 & 21 & 100,0 & 20 & 100,0 & 23 & 100,0 & 15 & 100,0 & 102 & 100,0 \\
\hline
\end{tabular}

$\%$ WLP=weight (overweight) loss percentage

TABLE 2 - Clinical conditions in the 12-month post-surgery follow-up in the study groups classified through score

\begin{tabular}{|c|c|c|c|c|c|c|c|c|c|c|c|c|}
\hline \multirow{2}{*}{ Clinical conditions $^{(1)}$} & \multicolumn{2}{|c|}{ Fobi-Capella } & \multicolumn{2}{|c|}{ Scopinaro } & \multicolumn{2}{|c|}{ D. switch } & \multicolumn{2}{|c|}{ Band } & \multicolumn{2}{|c|}{ Mason } & \multicolumn{2}{|c|}{ Total } \\
\hline & $\mathrm{n}$ & $\%$ & $\mathrm{n}$ & $\%$ & $\mathrm{n}$ & $\%$ & $\mathrm{n}$ & $\%$ & $\mathrm{n}$ & $\%$ & $n$ & $\%$ \\
\hline Worsened $^{(2)}$ & - & - & 01 & 4,8 & - & - & - & - & 01 & 6,7 & 02 & 1,9 \\
\hline Unchanged $^{(3)}$ & 09 & 39,1 & 03 & 14,3 & 01 & 5,0 & 14 & 60,9 & 08 & 53,3 & 35 & 34,3 \\
\hline Improved $^{(4)}$ & 03 & 13,1 & - & - & 01 & 5,0 & 02 & 8,7 & 01 & 6,7 & 07 & 6,9 \\
\hline One solved ${ }^{(5)}$ & 01 & 4,3 & 05 & 23,8 & 03 & 15,0 & 04 & 17,4 & 02 & 13,3 & 15 & 14,7 \\
\hline All solved(6) & 10 & 43,5 & 12 & 57,1 & 15 & 75,0 & 03 & 13,0 & 03 & 20,0 & 43 & 42,2 \\
\hline Total & 23 & 100,0 & 21 & 100,0 & 20 & 100,0 & 23 & 100,0 & 15 & 100,0 & 102 & 100,0 \\
\hline
\end{tabular}

TABLE 3 - Life quality questionnaire results in the study groups classified through scores

\begin{tabular}{|c|c|c|c|c|c|c|c|c|c|c|c|c|}
\hline \multirow{2}{*}{ Life Quality* } & \multicolumn{2}{|c|}{ Fobi-Capella } & \multicolumn{2}{|c|}{ Scopinaro } & \multicolumn{2}{|c|}{ Duodenal switch } & \multicolumn{2}{|c|}{ Band } & \multicolumn{2}{|c|}{ Mason } & \multicolumn{2}{|c|}{ Total } \\
\hline & $\mathrm{n}$ & $\%$ & $\mathrm{n}$ & $\%$ & $\mathrm{n}$ & $\%$ & $\mathrm{n}$ & $\%$ & $\mathrm{n}$ & $\%$ & $\mathrm{n}$ & $\%$ \\
\hline Highly decreased & - & - & 01 & 4,8 & - & - & - & - & - & - & 01 & 1,0 \\
\hline Decreased & 01 & 4,4 & - & - & 01 & 5,0 & - & - & 01 & 6,7 & 03 & 3,0 \\
\hline Unchanged & 01 & 4,3 & 02 & 9,5 & 03 & 15,0 & 06 & 26,1 & 02 & 13,3 & 14 & 13,7 \\
\hline Improved & 11 & 47,8 & 11 & 52,4 & 10 & 50,0 & 13 & 56,5 & 10 & 66,7 & 55 & 53,9 \\
\hline Highly improved & 10 & 43,5 & 07 & 33,3 & 06 & 30,0 & 04 & 17,4 & 02 & 13,3 & 29 & 28,4 \\
\hline TOTAL & 23 & 100,0 & 21 & 100,0 & 20 & 100,0 & 23 & 100,0 & 15 & 100,0 & 102 & 100,0 \\
\hline
\end{tabular}

* Not significant

TABLE 4 - Complications in the groups classified through scores

\begin{tabular}{|c|c|c|c|c|c|c|c|c|c|c|c|c|}
\hline \multirow{2}{*}{ Complications* } & \multicolumn{2}{|c|}{ Fobi-Capella } & \multicolumn{2}{|c|}{ Scopinaro } & \multicolumn{2}{|c|}{ Duodenal switch } & \multicolumn{2}{|c|}{ Band } & \multicolumn{2}{|c|}{ Mason } & \multicolumn{2}{|c|}{ Total } \\
\hline & $n$ & $\%$ & $n$ & $\%$ & $n$ & $\%$ & $\mathrm{n}$ & $\%$ & $n$ & $\%$ & $n$ & $\%$ \\
\hline No complications & 02 & 8,7 & 05 & 23,8 & 06 & 30,0 & 02 & 8,7 & 01 & 6,7 & 16 & 15,7 \\
\hline Significant & 10 & 43,5 & 08 & 38,1 & 05 & 25,0 & 01 & 4,3 & 05 & 33,3 & 29 & 28,4 \\
\hline Insignificant & 11 & 47,8 & 08 & 38,1 & 09 & 45,0 & 20 & 87,0 & 09 & 60,0 & 57 & 55,9 \\
\hline TOTAL & 23 & 100,0 & 21 & 100,0 & 20 & 100,0 & 23 & 100,0 & 15 & 100,0 & 102 & 100,0 \\
\hline
\end{tabular}

TABLE 5 - BAROS research protocol final classification of the assessed study groups

\begin{tabular}{|c|c|c|c|c|c|c|c|c|c|c|c|c|}
\hline \multirow{2}{*}{ Outcomes* } & \multicolumn{2}{|c|}{ Fobi-Capella } & \multicolumn{2}{|c|}{ Scopinaro } & \multicolumn{2}{|c|}{ Duodenal switch } & \multicolumn{2}{|c|}{ Band } & \multicolumn{2}{|c|}{ Mason } & \multicolumn{2}{|c|}{ Total } \\
\hline & $n$ & $\%$ & $\mathrm{n}$ & $\%$ & $\mathrm{n}$ & $\%$ & $\mathrm{n}$ & $\%$ & $\mathrm{n}$ & $\%$ & $\mathrm{n}$ & $\%$ \\
\hline Insufficient & - & - & 01 & 4,8 & - & - & 02 & 8,7 & 01 & 6,7 & 04 & 3,9 \\
\hline Acceptable & 02 & 8,7 & 02 & 9,5 & - & - & 08 & 34,8 & 05 & 33,3 & 17 & 16,7 \\
\hline Good & 06 & 26,1 & 05 & 23,8 & 05 & 25,0 & 06 & 26,1 & 02 & 13,3 & 24 & 23,5 \\
\hline Very good & 09 & 39,1 & 10 & 47,6 & 07 & 35,0 & 04 & 17,4 & 07 & 46,7 & 37 & 36,3 \\
\hline Excellent & 06 & 26,1 & 03 & 14,3 & 08 & 40,0 & 03 & 13,0 & - & - & 20 & 19,6 \\
\hline TOTAL & 23 & 100,0 & 21 & 100,0 & 20 & 100,0 & 23 & 100,0 & 15 & 100,0 & 102 & 100,0 \\
\hline
\end{tabular}

TABLE 6 - A) Descriptive statistics of total score of BAROS research protocol in the study groups; B) comparative analysis of the BAROS research protocol in the study groups

\begin{tabular}{|c|c|c|c|c|c|c|}
\hline \multicolumn{7}{|l|}{ A } \\
\hline Data & $n$ & Average & Standard-Diversion & Minimum & Maximum & Median \\
\hline Total geral & 102 & 4,5 & (1) 2,4 & $-2,0$ & 8,8 & 4,8 \\
\hline Fobi-Capella & 23 & 5,1 & (1) 1,9 & 0,6 & 8,1 & 5,0 \\
\hline Scopinaro & 21 & 4,8 & (1) 2,3 & $-2,0$ & 8,0 & 5,6 \\
\hline $\begin{array}{l}\text { Duodenal } \\
\text { Switch }\end{array}$ & 20 & 6,3 & 1,7 & 2,3 & 8,8 & - \\
\hline Banda & 23 & 2,9 & (1) 2,3 & $-0,7$ & 7,6 & 2,3 \\
\hline Mason & 15 & 3,0 & (1) 2,3 & $-2,0$ & 7,0 & 2,8 \\
\hline \multicolumn{7}{|l|}{ B } \\
\hline \multicolumn{3}{|c|}{ Data } & & \multicolumn{2}{|l|}{$\mathrm{p}^{(1)}$ value } & Significance \\
\hline \multirow{2}{*}{\multicolumn{3}{|c|}{ Grand Total }} & & $<0,0001$ & \multicolumn{2}{|c|}{ significativo } \\
\hline & & & itch & 0,029 & \multicolumn{2}{|c|}{ significativo } \\
\hline \multicolumn{3}{|c|}{ Fobi-Capella x Scopinaro } & & 0,990 & \multicolumn{2}{|c|}{ não significativo } \\
\hline \multicolumn{3}{|c|}{ Banda x Mason } & & 0,654 & \multicolumn{2}{|c|}{ não significativo } \\
\hline
\end{tabular}


than in the vertical banded gastroplasty. Therefore, that is the reason why authors use gastrojejunal diversion as a standard procedure and use gastroplasty only in selected cases $^{23}$. Such result is similar to that described in the present study.

Few papers use BAROS and most of them show incomplete results concerning pre and post-surgery BMI and overweight percentage reduction. In addition, post-surgery follow-up period of time is not homogeneous, what makes it difficult to compare different techniques. Presently, reports on bariatric surgery results are not standardized, thus hampering deeper studies of issues such as co-morbidities and life quality. Literature does not have any study comparing the five techniques used with BAROS.

It is very important to carry out further studies using BAROS to compare surgery results. BAROS is not perfect, it has failures in its conception and several criteria should be assessed and updated. Presently, however, is the only existing tool which permits global comparison of different technique results. Its upgrading is fundamental to improve the ability to measure the results of different surgeons, patients and surgery techniques, thus contributing to the bariatric surgery development.

Although there are some differences concerning life quality, weight loss, clinical conditions, complications, redonesurgeries, BAROS results and research method variations, the present study results are similar to those described in the relevant literature.

\section{CONCLUSION}

According to BAROS assessment of the post-surgery 12-month follow-up, biliopancreatic diversion is the best technique to treat morbid obesity.

\section{REFERENCES}

1. Alvarez-Cordero R, Aragón-Viruette E. Comparative analysis of three bariatric techniques with the BAROS system. Obes Surg. 1999; 9(2):131-2.

2. Baltasar A, Bou R, Miró J, Bengochea M, Arlandis F, Escrivá C, Pérez $\mathrm{N}$, Serra C, Martinez R. Intermediate Results of the Duodenal Switch Operation. Obes Surg. 2000; 10(4):332

3. Barroso FL, Alonso AS, Leite MA. Complicações Cirúrgicas Intraoperatórias e do Pós-operatório Recente. In: Garrido Jr AB, Ferraz EM, Barroso FL, Marchesini JB, Szego T. Cirurgia da obesidade. Sociedade Brasileira de Cirurgia Bariátrica. São Paulo: Atheneu, 2002. p. 215-225. 47

4. Berti LV, Oliveira MR, Garrido Jr AB. Gastroplastia Vertical com Bandagem. In: Garrido Jr AB, Ferraz EM, Barroso FL, Marchesini JB, Szego T. Cirurgia da obesidade. Sociedade Brasileira de Cirurgia Bariátrica. São Paulo: Atheneu, 2002. p. 149-154. 68

5. Brolin RE. Complications of Surgery for Severe Obesity. Problems in General Surgery, Danvers, v. 17, n. 2, p. 55-61, Jun. 2000. 33

6. Buchwald H. A bariatric surgery algorithm. Obes Surg. 2002 Dec;12(6):733-46.

7. Dhabuwala A, Cannan RJ, Stubbs RS. Improvement in co-morbidities following weight loss from gastric bypass surgery. Obes Surg. 2000 Oct:10(5):428-35.

8. Dixon JB, O'Brien PE.Changes in comorbidities and improvements in quality of life after LAP-BAND placement. Am J Surg. 2002 Dec;184(6B):51S-54S.

9. Faintuch J, Rudner MA, Machado PLRC, Garrido Jr AB, Oliveira MR, Gama-Rodrigues JJ. Response of Comorbidities to Roux-en-Y Gastric Bypass (RYGBP). Obesity Surgery, New York, v. 11, n. 4, p.
430, Aug. 2001(b). 17

10. Favretti F, Cadiere GB, Segato G, Busetto L, Loffredo A, Vertruyen M, Enzi G, Caniato D, De Marchi F, Lise M. Bariatric analysis and reporting outcome system (BAROS) applied to laparoscopic gastric banding patients. Obes Surg. 1998 Oct;8(5):500-4.

11. Forsell P, Hallerbäck B, Glise H, Hellers G. Complications following Swedish adjustable gastric banding: a long-term follow-up. Obes Surg. $1999 \mathrm{Feb} ; 9(1): 11-6$.

12. Garrido Jr. AB, Oliveira MR, Berti LV, Elias AA, Pareja JC, Matsuda M, Gama-Rodrigues JJ. Derivações Gastrojejunais. In: Garrido Jr AB, Ferraz EM, Barroso FL, Marchesini JB, Szego T. Cirurgia da obesidade. Sociedade Brasileira de Cirurgia Bariátrica. São Paulo: Atheneu, 2002. p. $155-161.69$

13. Hell E, Miller KA, Moorehead MK, Norman S. Evaluation of health status and quality of life after bariatric surgery: comparison of standard Roux-en-Y gastric bypass, vertical banded gastroplasty and laparoscopic adjustable silicone gastric banding. Obes Surg. 2000 Jun;10(3):214-9.

14. Higa KD, Boone KB, Ho T. Complications of the laparoscopic Rouxen-Y gastric bypass: 1,040 patients--what have we learned? Obes Surg. 2000 Dec;10(6):509-13.

15. Marceau P, Biron S, Hould F, Lebel S, Marceau S. Malabsorption Procedure in Surgical Treatmente of Morbid Obesity. Problems in General Surgery, 2000;17(2):29-38.

16. MarchesiniJB, Marchesini JCD. Insucesso Terapêutico, Complicações Tardias e Re-operações. In: Garrido Jr AB, Ferraz EM, Barroso FL, Marchesini JB, Szego T. Cirurgia da obesidade. Sociedade Brasileira de Cirurgia Bariátrica. São Paulo: Atheneu, 2002. p. 227-244. 48

17. Marinari GM, Murelli F, Camerini G, Papadia F, Carlini F, Stabilini C, Adami GF, Scopinaro N. A 15-year evaluation of biliopancreatic diversion according to the Bariatric Analysis Reporting Outcome System (BAROS). Obes Surg. 2004 Mar;14(3):325-8.

18. Melissas J, Christodoulakis M, Schoretsanitis G, Sanidas E, Ganotakis E, MichaloudisD, TsiftsisDD.Obesity-associated disordersbeforeand after weight reduction by vertical banded gastroplasty in morbidly vs super obese individuals. Obes Surg. 2001 Aug;11(4):475-81.

19. Nanni G, Balduzzi G, Capoluongo R, Rosso G, Botta C, Demichelis P, Dalfara M, Scansetti M, Pruneri U. Biliopancreatic Diversion For Obesity: Quality of Life Evaluation. Obesity Surgery. 2000;10(4):313.

20. O'Brien PE, Dixon JB. Weight loss and early and late complications-the international experience. Am J Surg. 2002 Dec;184(6B):42S-45S.

21. Oria HE, Moorehead MK. Bariatric analysis and reporting outcome system (BAROS). Obes Surg. 1998 Oct;8(5):487-99.

22. Pories WJ, MacDonald KG Jr, Morgan EJ, Sinha MK, Dohm GL, Swanson MS, Barakat HA, Khazanie PG, Leggett-Frazier N, Long $\mathrm{SD}$, et al. Surgical treatment of obesity and its effect on diabetes: 10-y follow-up. Am J Clin Nutr. 1992 Feb;55(2 Suppl):582S-585S.

23. Sala C, Ortega J, López F, García S, Martinez-Valls J, Liedo S. Use of BAROS. Score System in Patients Operated on for Morbid Obesity: Results of Our Series Obesity Surgery. 2001;11(4):433-434.

24. Schauer PR, Ikramuddin S, Gourash W, Ramanathan R, Luketich J. Outcomes after laparoscopic Roux-en- $Y$ gastric bypass for morbid obesity. Ann Surg. 2000 Oct;232(4):515-29.

25. Scopinaro N, Marinari GM, Adami G, Traverso E, Camerini G, Campostano A. The effect of biliopancreatic diversion on glucose and cholesterol metabolism. Obesity Surgery. 1998;8(2):151.

26. Suter $M$, Jayet $C$, Jayet $A$. Vertical banded gastroplasty: long-term results comparing three different techniques. Obes Surg. 2000 Feb;10(1):41-6.

27. Tacchino RM, Nanni G, Foco M, Sollazzi L, Perilli W, Castagneto M. Ten years of experience with biliopancreatic diversion for treatment of obesity. Obesity Surgery. 1999;2:127

28. Victorzon M, Tolonen P. Bariatric Analysis and Reporting Outcome System (BAROS) following laparoscopic adjustable gastric banding in Finland. Obes Surg. 2001 Dec;11(6):740-3.

29. Wittgrove AC, Clark GW. Laparoscopic gastric bypass, Roux-en-Y500 patients: technique and results, with 3-60 month follow-up. [see comment] Obes Surg. 2000;10(3):233-239

30. Wolf AM, Falcone AR, Kortner B, Kuhlmann HW. BAROS: an effective system to evaluate the results of patients after bariatric surgery. Obes Surg. 2000 Oct;10(5):445-50. 